\title{
Legemidler til røykeslutt på blå resept?
}

\author{
Regjeringen bør fjerne nikotinavhengighet fra «moralparagrafen» i legemiddelforskriften, slik at legemidler \\ til hjelp ved røykeslutt kan skrives på blå resept.
}

De første studiene som viste at tobakksrøyking skader helsen, kom allerede i 1950årene $(1,2)$. Siden da har myndigheter i flere land kjempet en knallhard kamp mot røyking. I Norge ble tobakkskadeloven innført i 1973. Paragraf 12, eller røykeloven som den heter på folkemunne, ble tilføyd i 1988. I 2003 kom et forbud mot røyking på serveringssteder. Samme år vedtok Verdens helseforsamling tobakkskonvensjonen, som er juridisk bindende i 180 land.

Røyking er en av de verste og viktigste risikofaktorene for utvikling av en rekke sykdommer. Forfatterne bak Global Burden of Disease-studien fant ut at tobakksrøyking var årsak til 6,1\% av den globale sykdomsbyrden (3). Tall fra Danmark viser at røykere og tidligere røykere forårsaket 2,7 millioner ekstra konsultasjoner hos allmennlegene og sto for 150000 ekstrainnleggelser på sykehus per år. Danske tall viser også at røyking årlig forårsaket 2,5 millioner sykefraværsdager (4). I Norge har man beregnet at røyking koster helsevesenet ca. 3,8 milliarder kroner i året. Estimatet inkluderer da ikke kostnader knyttet til sykefravær, tidlig pensjon og tidlig død (5).

\section{Virkemidler}

Norske myndigheter har tatt i bruk flere virkemidler for å bekjempe røykingen. Leger er viktige samarbeidspartnere i denne langvarige kampen mot nikotinen. Leger kan tilby motivasjonssamtaler og/eller forskrive farmakologiske hjelpemidler for å få flere til å stumpe røyken. For tiden er det tre hovedgrupper av farmakologiske hjelpemidler som er tilgjengelig på markedet: røykeerstatninger, bupropion og vareniklin.

Røykeerstatninger er ikke reseptbelagte. Det er derimot bupropion og vareniklin. Flere studier har vist at begge disse midlene er effektive. En oppsummeringsrapport viser at $26 \%$ av dem som prøvde vareniklin og $18 \%$ av dem som prøvde bupropion forholdt seg røykfrie sammenliknet med placebogruppen der kun $10 \%$ forholdt seg røykfrie etter ett år (6). Disse midlene var ikke bare effektive, men også kostnadseffektive, viser rapporten fra Kunnskapsenteret (6).
Likevel kan ingen av disse midlene skrives på blå resept $\mathrm{i}$ forbindelse med røykeslutt.

\section{«Moralparagrafen»}

For at et medikament skal omfattes av blåreseptordningen må det blant annet være forhåndsgodkjent. Per dags dato er det fire tilstander som legemiddelprodusentene ikke kan søke om forhåndsgodkjenning for. Unn-

\section{«Samfunnet vinner både leveår og helse- kroner på å få flere til å slutte å røyke»}

takene omtales av § 14-14 - også kjent som moralparagrafen - i legemiddelforskriften. Navnet kommer av at man i sin tid ikke anså disse tilstandene som sykdom. Tilstandene som er omtalt av moralparagrafen er erektil dysfunksjon, rusmiddelavhengighet, nikotinavhengighet og naturlig hårtap.

Regjeringen foreslår i legemiddelmeldingen å fjerne begrensningene på legemidler mot rusavhengighet og erektil dysfunksjon, slik at disse midlene i fremtiden kan skrives ut på blå resept (7). Dette er vel og bra for pasientene som omfattes av de foreslåtte endringene. Men regjeringen burde også ha benyttet anledningen til å fjerne begrensningene på legemidler mot nikotinavhengighet.

Til tross for mange gode tiltak, dør fortsatt over 6000 nordmenn hvert år på grunn av røyking (8). Dette er altfor mange. Norske myndigheter har sluttet seg til Verdens helseorganisasjons mål om å redusere for tidlig død med $25 \%$ innen 2025 (NCD-målene). Som regjeringen selv påpeker i folkehelsemeldingen: «Det er stort potensial i å legge mer til rette for røykeslutt. Dersom vi skal nå NCD-målene innen 2025, er dette også helt nødvendig» (9).

Samfunnet vinner både leveår og helse- kroner på å få flere til å slutte å røyke. Derfor burde politikerne fjerne også nikotinavhengighet fra moralparagrafen når legmiddelmeldingen skal behandles i helseog omsorgskomiteen på nyåret.

\section{Naresh Sugandiran}

n.sugandiran@gmail.com

Naresh Sugandiran (f. 1984) er medisinstudent på sisteåret ved Universitetet i Oslo.

Forfatter har fylt ut ICMJE-skjemaet og oppgir ingen interessekonflikter.

\section{Litteratur}

1. Doll R, Hill AB. Lung cancer and other causes of death in relation to smoking; a second report on the mortality of British doctors. BMJ 1956; 2 1071-81.

2. Doll R, Hill AB. Smoking and carcinoma of the lung; preliminary report. BMJ 1950; 2: 739-48.

3. Lim SS, Vos T, Flaxman AD et al. A comparative risk assessment of burden of disease and injury attributable to 67 risk factors and risk factor clusters in 21 regions, 1990-2010: a systematic analysis for the Global Burden of Disease Study 2010. Lancet 2012; 380: 2224-60.

4. Juel K, Sørensen J, Brønnum-Hansen H. Risikofaktorer og folkesundhed i Danmark. København: Statens Institut for Folkesundhed, 2006.

5. Sælensminde K, Torkilseng E. Samfunnsøkonomiske kostnader av røyking - En vurdering av metodikk og kostnadenes størrelsesorden. Oslo: Helsedirektoratet, 2010

6. Sæterdal I, Ringerike T, Odgaard-Jensen J et al. Legemidler til røykeslutt. Oslo: Nasjonalt kunnskapssenter for helsetjenesten, 2010.

7. Meld. St. 28 (2014-2015). Legemiddelmeldingen: Riktig bruk - bedre helse. www.regjeringen.no/no/ dokumenter/meld.-st.-28-20142015/id2412810/ (16.11.2015).

8. Vollset S, Selmer R, Tverdal A et al. Hvor dødelig er røyking? - Rapport om dødsfall og tapte leveår som skyldes røyking. Oslo: Folkehelseinstituttet, 2006

9. Meld. St. 19 (2014-2015). Folkehelsemeldingen Mestring og muligheter. https://www.regjeringen. no/no/dokumenter/meld.-st.-19-2014-2015/ id2402807/ (16.11.2015)

Mottatt 11.11. 2015 og godkjent 16.11. 2015. Redaktør: Martine Rostadmo.

Publisert først på nett. 